\title{
РОЗВИТОК І СТАНОВЛЕННЯ ЕМБРІОТОПОГРАФІЇ ПЕРЕДНЬОЇ СТІНКИ БАРАБАННОЇ ПОРОЖНИНИ В РАННЬОМУ ПЕРІОДІ ОНТОГЕНЕЗУ ЛЮДИНИ
}

Вищий державний навчальний заклад України «Буковинський державний медичний університет», м. Чернівці

Резюме. Розвиток передньої стінки барабанної порожнини вивчений на препаратах 44 плодів людини 4-8 місяців. Встановлено, що передня стінка барабанної порожнини починає формуватися на 8-му місяці внутрішньоутробного розвитку, у цьому процесі бере участь внутрішня сонна артерія. Внаслідок розвитку передньої стінки барабанної порожнини барабанні отвори слухових труб починають переміщуватися із нижньої частини барабанної порожнини доверху.

Ключові слова: анатомія, барабанна порожнина, внутрішня сонна артерія, внутрішньоутробний розвиток, слухова труба.
Вступ. За останні 10 років у розвинутих країнах відсоток передчасно народжених дітей залишається стабільним і становить 5-12 \% всіх новонароджених [1]. Тяжкий соматичний стан їх вимагає проведення реанімаційних заходів із тривалим використанням ШВЛ і СРАР-терапії, а також допоміжного годування через назогастральний зонд.

За даними деяких авторів [2, 9], застосування СРАР у 30-35 \% випадків призводить до травмування зовнішнього носа, і ці ятрогенні зміни виникають вже на 3-тю добу [7].

Тривалий компресійний вплив біназальної канюлі, інтубаційної трубки та назогастрального зонда в носовій порожнині призводить до деструктивних змін у останній та носовій частині глотки. Все це, а також постійне горизонтальне положення дитини призводить до затяжних ринітів, що, у свою чергу, може викликати запалення слухової труби і середнього вуха, виникнення ускладнень і необхідність хірургічного втручання [1]. Зазначимо, що прицільна робота на даних структурах вимагає точного знання топографоанатомічних особливостей будови скроневої кістки, у тому числі й у цій віковій групі [5].

У сучасній літературі достатньо докладно описані типова і варіантна анатомія та вади розвитку барабанної порожнини $[6,8]$, а також можливі оперативні підходи в цій ділянці, але тільки в поодиноких роботах можна виявити дані про вікові анатомічні особливості структур барабанної порожнини.

Також слід зауважити, що порушення ембріогенезу можуть призвести до патології слуху, що, у свою чергу, викликає зміни психоемоціонального розвитку та соціальну дезадаптацію дитини [3].

Ембріологічні дослідження дозволяють встановити терміни та механізми виникнення індивідуальних варіантів нормальної будови та аномалій розвитку [4]. Тому вивчення особливостей морфогенезу і становлення топографії середнього вуха, його індивідуальної анатомічної мінливості у плодів та новонароджених людини залишається актуальним і пріоритетним.

Мета дослідження. 3'ясувати особливості розвитку передньої стінки барабанної порожнини в ранньому періоді онтогенезу людини та обгрунту-

(с) О.Д. Сапунков, А.Л. Косаківський, Л.О. Сапункова, 2016 168 вати морфологічний взаємозв'язок формоутворювальних процесів його із суміжними структурами.

Матеріал і методи. Дослідження виконано на препаратах 44 плодів людини 81,0-310,0 мм тім'яно-куприкової довжини (ТКД) без зовнішніх анатомічних відхилень або аномалій розвитку кісток черепа. У ході дослідження використаний комплекс морфологічних методів: тонкого анатомічного препарування складових середнього вуха та прилеглих ділянок під контролем бінокулярної лупи, макро- та мікроскопії, морфометрії, макрофотографії цифровим фотоапаратом “OLIMPUS н 1000 All-weather 10,0 MPix" і статистичної обробки отриманих результатів.

Результати дослідження та їх обговорення. На початку плодового періоду онтогенезу (81,0135,0 мм ТКД) барабанна порожнина являє собою щілиноподібний простір, який розміщений у горизонтальній площині, поступово звужується у вентральному напрямку та переходить у слухову трубу. Барабанне кільце змикається 3 присередньою стінкою барабанної порожнини на всьому протязі, окрім своєї верхньої частини, що вказує на відсутність передньої, нижньої та задньої стінок барабанної порожнини (рис. 1). Сонний канал, через який прямує внутрішня сонна артерія, визначається на внутрішній поверхні скроневої кістки під кутом $20^{\circ}$ відносно основи черепа i його діаметр становить $0,43 \pm 0,02$ мм.

На п'ятому місяці внутрішньоутробного розвитку (плоди 136,0-185,0 мм ТКД) форма та розташування барабанної порожнини суттєво не змінюються (рис. 2). Сонний канал розміщений на внутрішній поверхні скроневої кістки під кутом відносно основи черепа $25^{\circ}$ і його діаметр становить $0,56 \pm 0,02$ мм (рис. 3).

У плодів 6-го місяця розвитку (186,0-230,0 мм ТКД) нижній край барабанного кільця щільно прилягає до лабіринтної стінки (рис. 4), а верхній відходить від неї, що призводить до утворення кута, спрямованого вершиною латерально. Розширена частина клина утворює надбарабанну заглибину. Барабанна порожнина на цій стадії розвитку ще не має нижньої та передньої стінок, форма іiї клиноподібна. Сонний канал проходить 


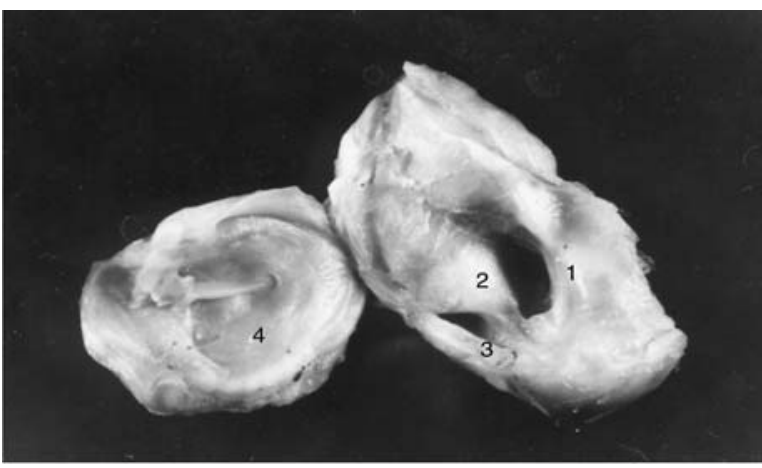

Рис. 1. Сагітальний розріз барабанної порожнини плода 81,0 мм ТКД. Макропрепарат. Зб. 3,8 $: 1$ - вікно присінка; 2 - мис; 3- вікно завитки; 4 - барабанна перетинка

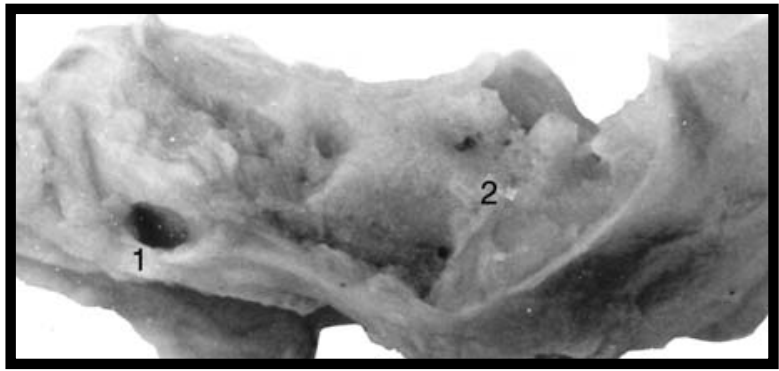

Рис. 3. Скронева кістка плода 180,0 мм ТКД (вигляд знизу). Макропрепарат. 3б. 3,2 1 - сонний канал; 2 яремна ямка

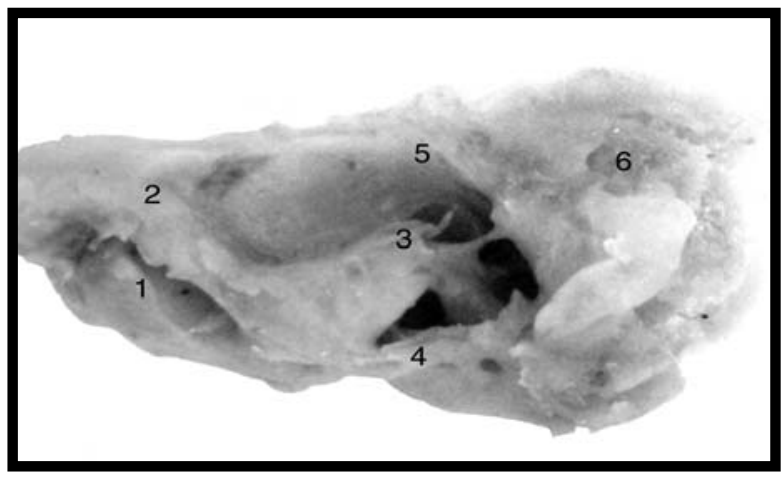

Рис. 5. Сагітальний розріз скроневої кістки плода 195,0 мм ТКД. Макропрепарат. 3б. 3,2x: 1 - сонний канал; 2 - слухова труба; 3 - вікно присінка; 4 -вікно завитки; 5 - канал лицевого нерва; 6 - печера соскоподібного відростка

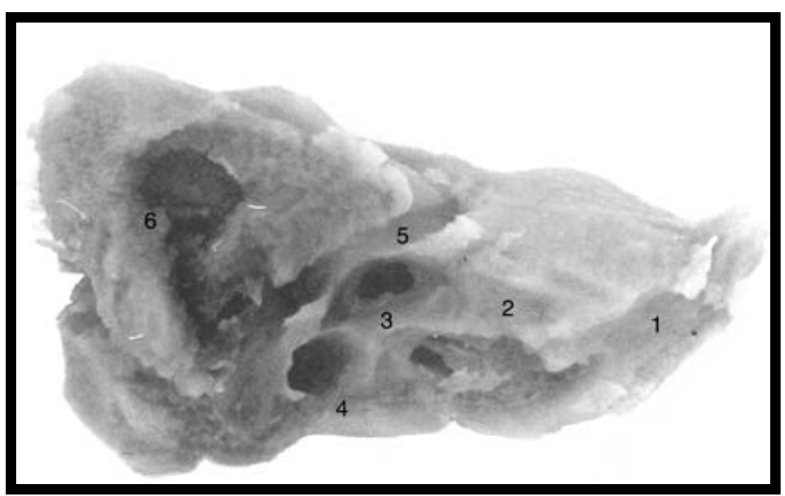

Рис. 7. Сагітальний розріз скроневої кістки плода 280,0 мм ТКД. Макропрепарат. Зб. 3,2x: 1 - сонний канал; 2 - слухова труба; 3 - вікно присінка; 4 - вікно завитки; 5 - канал лицевого нерва; 6 - печера соскоподібного відростка

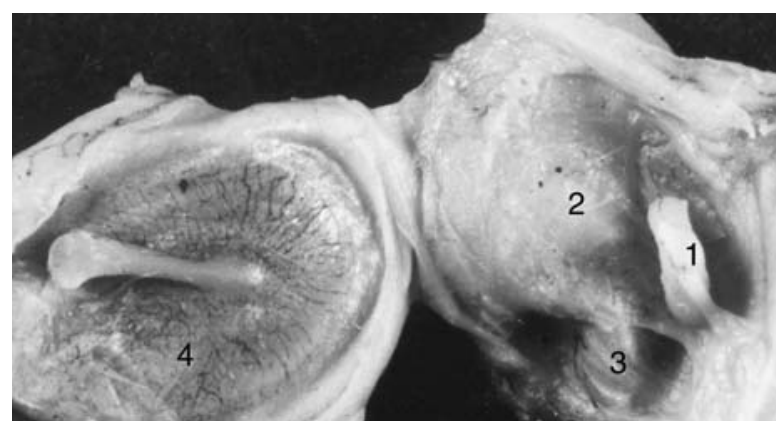

Рис. 2. Сагітальний розріз барабанної порожнини плода 155,0 мм ТКД. Макропрепарат. 3б. 3,8 $: 1$ - вікно присінка; 2 - мис; 3- вікно завитки; 4 - барабанна перетинка

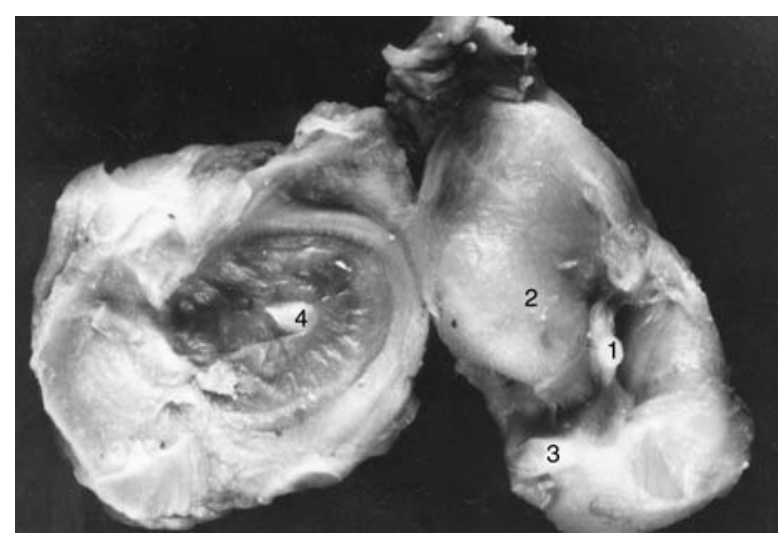

Рис. 4. Сагітальний розріз барабанної порожнини плода 230,0 мм ТКД. Макропрепарат. Зб. 3,8 ${ }^{\mathrm{x}}: 1$ - вікно присінка; 2 - мис; 3 - вікно завитки; 4 - барабанна перетинка

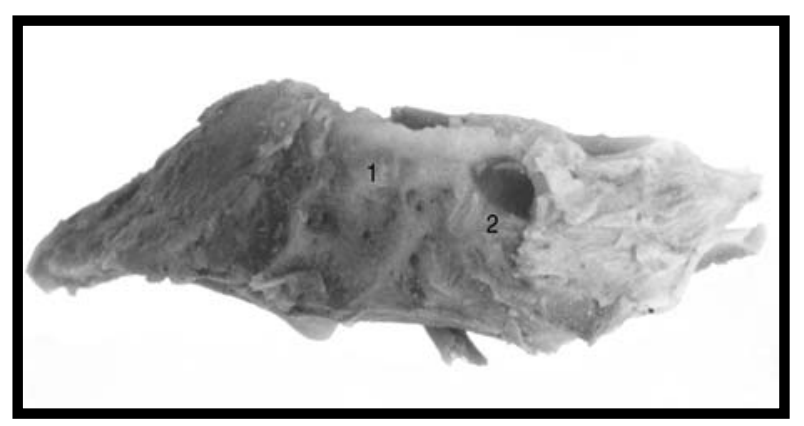

Рис. 6. Скронева кістка плода 195,0 мм ТКД (вигляд знизу). Макропрепарат. Зб. $3,2^{\mathrm{x}}$ : 1 - яремна ямка, 2 - сонний канал

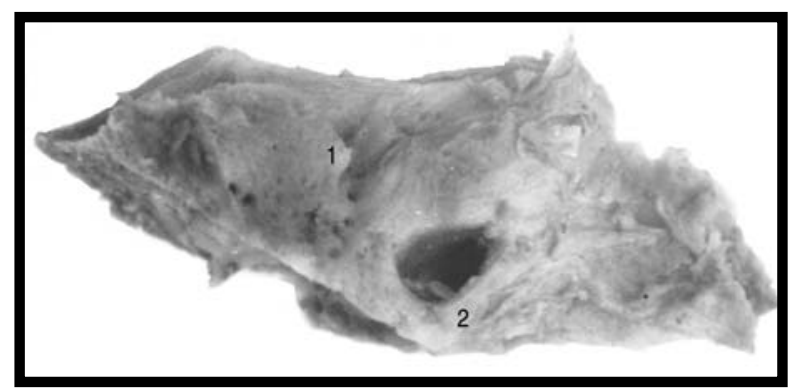

Рис. 8. Скронева кістка плода 290,0 мм ТКД (вигляд знизу). Макропрепарат. Зб. 3,2 $2^{\mathrm{x}} 1$ - яремна ямка; 2 - сонний канал 
під кутом $30^{\circ}$ до основи черепа (рис. 5), діаметр його дорівнює $0,71 \pm 0,03$ мм (рис. 6).

У 7-місячних плодів (231,0-270,0 мм ТКД) форма та розташування барабанної порожнини істотно не змінюються. Сонний канал діаметром $0,93 \pm 0,03$ мм проходить під кутом $35^{\circ}$ до основи черепа.

На 8-му місяці внутрішньоутробного розвитку (плоди 271,0-310,0 мм ТКД) починає формуватися передня стінка барабанної порожнини. Формуванню іiі сприяє збільшення розмірів внутрішньої сонної артерії, адже відповідно до цього збільшується і сонний канал. Під час цього процесу барабанне кільце переходить із горизонтального положення в похиле, а барабанні отвори слухових труб починають зміщуватися доверху. Сонний канал проходить під кутом $40^{\circ}$ до основи черепа (рис. 7), діаметр його становить $1,18 \pm 0,04$ мм (рис. 8 ). Товщина передньої стінки становить $0,35 \pm 0,01$ мм.

\section{Висновки}

1. Початок формування передньої стінки барабанної порожнини спостерігається у плодів восьми місяців. На цій стадії розвитку барабанні отвори слухових труб починають переміщуватися до верхньої частини передньої стінки барабанної порожнини.

2. На процес формування передньої стінки барабанної порожнини впливає збільшення розмірів внутрішньої сонної артерії.

3. Визначені топографо-анатомічні особливості мають важливе значення для удосконалення технологій і адекватності хірургічного лікування та маніпуляцій на середньому вусі у передчасно народжених дітей.

\section{Література}

1. Важность исследования ЛОР-органов у недоношенных детей / И.В. Рахманова, Р.В. Котов, О.А. Бабак [и др.] // Вестн. отоларингол. - 2010. - № 3. - С. 12-14.

2. Комплексная профилактика посттравматических изменений носа у новорожденных детей, находящихся в отделениях реанимации и интенсивной терапии (медицинская технология) / И.В. Рахманова, В.Р. Котов, В.В. Раш [и др.]. - М.: ГБОУ ВПО РНИМУ им. Н.И. Пирогова, 2012. - 24 с.

3. Новые возможности реабилитации пациентов с врожденными пороками развития наружного и среднего уха / Н.А. Милешкина, С.С. Осипенков, В.В. Бакшинян [и др.] // Вестн. отоларингол. - 2014. - № 2. C. 33-36.

4. Петренко В.М. Развитие человека: вопросы развития в анатомии человека / В.М. Петренко. - М.-Берлин: Директ-Медиа, 2015. - С. 3-6, С. 112-116.

5. Cinamon $\mathrm{U}$. The growth rate and size of the mastoid air cell system and mastoid bone: a review and reference / U. Cinamon // European Archives Oto-RhinoLaryngology. - 2009. - Vol. 266, № 6. - P. 781-786.

6. Ontogenetic landmarks of the organ of hearing in fetal age determination / George Lupu, Daniel Popescu, Victor Panus, Gabriela Popescu // Rom. J. Leg. Med. - 2010. № 2. - P. 129-132.

7. Posttraumatic damages of nasal soft tisses under CPAP and methods of their prevention / V.V. Rush, I.V. Rakhmanova, M.R. Bogomilsky, N.N. Volodin // The J. of Maternal-Fetal and Neonatal Medicine. - 2010. Vol. 23, № 1. - P. 607.

8. Tamrazi B. Imaging of Pediatric Hearing Loss / B. Tamrazi, J. Almast, R. Mangla // Neurographics. - 2011. Vol. 1, № 2. - P. 66-73.

9. Yong S.C. Incidence of nasal trauma associated with nasal prong versus nasal mask during continuous positive airway pressure treatment in very low birthweight infants: a randomized control study / S.C. Yong, S.J. Chen, N.Y. Boo // Arch Dis Child Fetal Neonatal ED. - 2005. Vol. 90, № 6. - P. 480-483.

\section{РАЗВИТИЕ И С ТАНОВЛЕНИЕ ЭМБРИОТОПОГРАФИИ ПЕРЕДНЕЙ СТЕНКИ БАРАБАННОЙ ПОЛОСТИ В РАННЕМ ПЕРИОДЕ ОНТОГЕНЕЗА ЧЕЛОВЕКА}

\section{О.Д. Сапунков, А.Л. Косаковский, Л.О. Сапункова}

Резюме. Развитие передней стенки барабанной полости изучено на препаратах 44 плодов человека. Установлено, что передняя стенка барабанной полости начинает формироваться на восьмом месяце внутриутробного развития. В этом процессе принимает участие внутренняя сонная артерия. Вследствии развития передней стенки барабанной полости барабанные отверстия слуховых труб начинают перемещаться из нижней части барабанной полости вверх.

Ключевые слова: анатомия, барабанная полость, внутренняя сонная артерия, внутриутробное развитие, слуховая труба.

\section{DEVELOPMENT AND FORMATION OF THE EMBRYOTOPOGRAPHY OF THE ANTERIOR WALL OF THE TYMPANUM IN EARLY PERIOD OF HUMAN ONTOGENESIS}

\section{O.D. Sapunkov, A.L. Kosakovskyi, L.O. Sapunkova}

Abstract. Development of the front wall of the tympanic cavity was studied on preparations of 44 human fetuses. It was found that the front wall of the tympanic cavity begins to form in its 8 th month of fetal development. The internal carotid artery is involved in this process. Owing to the development of the front wall of the tympanic cavity the tympanic hole of the auditory tubes start to move from the bottom upwards.

Key words: anatomy, tympanic cavity, internal carotid artery, prenatal development, auditory tube.

Higher State Educational Institution of Ukraine "Bukovinian State Medical University” (Chernivtsi)

Рецензент - проф. Т.В. Хмара
Buk. Med. Herald. - 2016. - Vol. 20, № 3 (79). - P. 168-170

() О.Д. Сапунков, А.Л. Косаківський, Л.О. Сапункова, 2016 